
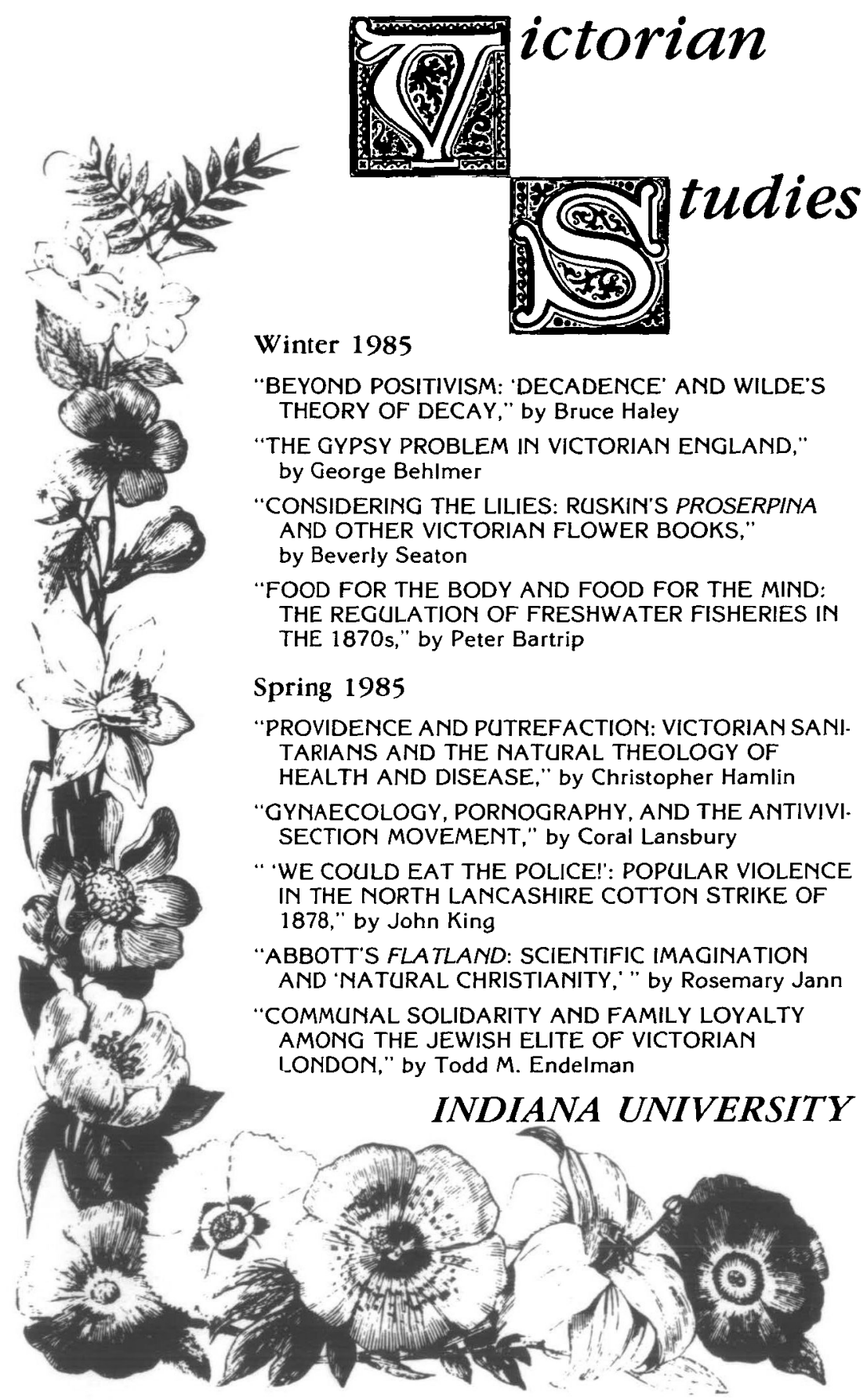


\section{History of Science}

Membership of the Society, which includes a subscription to The British Journal for the History of Science, is open to all persons approved by the Council of the Society and elected at an ordinary meeting (formalities required by the UK Companies Act). The annual subscription for the membership year ${ }_{1985-86}$ is $£^{1} 3.00$ (US\$26.oo in the Americas, Canada, and Japan) or for students, f6.50, $\left.^{6} \$_{13} .00\right)$.

Applications for membership should be made on a form which is available from the Society's Executive Secretary at the address below.

Meetings: The Society mounts an ambitious programme of meetings. The pattern is flexible, the only fixture being the three-day summer meeting, held at a different British University or Polytechnic each year. About four other meetings, lasting for between one and three days, are held during the year, sometimes-devoted to a clearly-defined theme or an important anniversary, and often arranged in conjunction with other scholarly societies.

The British fournal for the History of Science is the official organ of the Society. All correspondence on the contents of the Journal should be addressed to the Editor, Dr David Knight, Department of Philosophy, University of Durham, 50 Old Elvet, Durham $\mathrm{DH}_{1}{ }_{3} \mathrm{HN}$, England.

Books for review should be sent to the Reviews Editor, Dr John Hendry, $5^{8}$ Canfield Gardens, London NW6 ${ }_{3}$ EB.

Advertising: Contact Sue Barklie, Advertising Department, Blackwell Scientific Publications, Osney Mead, Oxford, OX 2 oEL.

Orders and back issues: Orders for the Journal and inquiries about back issues should be addressed to the Blackwell Scientific Publications. Claims for missing copies should be made within six months of publication. The 1985 subscription rate for non-members is $£ 30.00\left(\$_{52} .00\right)$.

Other publications: BSHS Monograph Series is designed to allow the publication of monographic studies in the history of science quickly and cheaply. All correspondence on the subject of monographs, and any new suggestions for titles, should be sent to the Series Editor, Dr J.G. Smith, Department of History, University of Loughborough, Loughborough, Leics LEIr 3 TU, England. Monographs are available to members at a special price, post-free from the Society's Administrator. Non-members may obtain them through bookshops, or post-free from the Administrator. Now available:

1. Images of the earth: essays in the history of the environmental sciences. Ed. by L. J. Jordanova and Roy Porter. 1979. $£ 7.50 / \$ 15.00$ ( $£ 5.00 / \$ 10.00$ to members).

2. The letters of Georges Cuvier: a summary calandar. Ed. by Dorinda Outram. 1980.

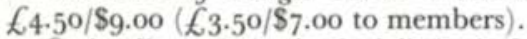

3. Rationality and ritual: the Windscale Inquiry and nuclear decisions in Britain. By Brian Wynne. $£ 7.00 / \$ 14.00$ ( $£ 5.00 / \$ 10.00$ to members).

4. The Royal Society and its Fellows $1660-1700$ : the morphology of an early scientific institution. By Michael Hunter. $f 9.00 / \$_{1} 8.00\left(f_{6.50} / \$_{1} 3.00\right)$.

5. Francis Bacon's Natural Philosophy: A New Source. A Transcription of Manuscript Hardwick $72 \mathrm{~A}$ with Translation and Commentary. By Graham Rees assisted by Christopher Upton. $£ 7.90 / \$_{15.50}\left(£ 5.60 / \$_{11} .00\right.$ to members).

List of theses: Every December, the Society publishes a full list of current theses in history of science in British universities. This is available free to members, and at a small charge to non-members on request to the Executive Secretary. Standing orders are accepted from members or non-members who wish to receive the list regularly.

The Society's Newsletter, an informal publication edited by Dr. Mari Williams, Business History Unit, Lionel Robbins Building, to Portugal Street, London $W_{2} \mathrm{~A}{ }_{2} \mathrm{HD}$, appears in January, May and September each year. It is free to members, $£ 4.50$ for institutions and non-members.

All the administrative business of the Society is handled by 


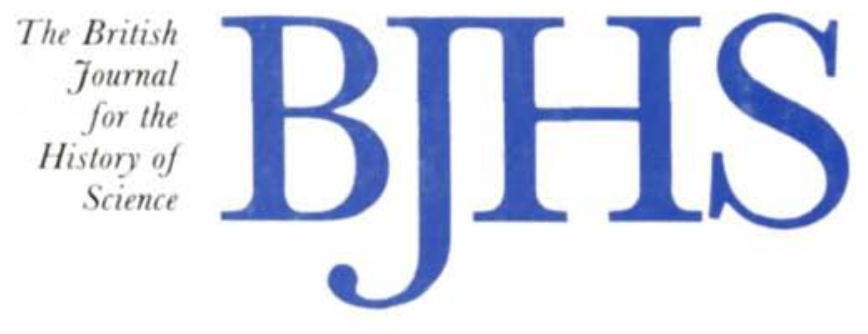

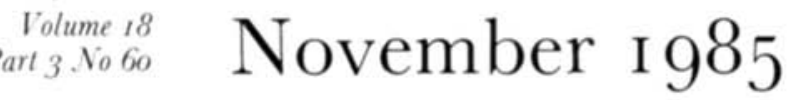

255 Roger L. Emerson: The Philosophical Society of Edinburgh, 1 $768-1783$

305 Ludmilla Schulze: The Russification of the St. Petersburg Academy of Sciences and Arts in the Eighteenth Century

Note

337 Margaret Campbell: Pairing in Mendel's Theory

34 I Obituaries: Eric Forbes ( $1933^{-1984}$ )

Bernard Norton (1945-1984)

345 Book Reviews

373 Report of Council for ${\text { I } 984^{-5}}^{-5}$

$376 \quad$ Books Received

Index of Books Reviewed

Published by The British Society for the History of Science

Registered Office: Halfpenny Furze, Mill Lane,

Chalfont St Giles, Bucks HP8 ${ }_{4} \mathrm{NR}$

Price: f $_{\mathrm{i} 0.00}$ or $\$ 20.00$ including postage

(Free to members of the Society)

C. The British Society for the History of Science 1985 